\title{
STUDY OF TRADITIONAL USES OF MEDICINAL SHRUBS IN BEGNAS-RUPA LAKE AREA
}

\author{
Om Prasad Dwa ${ }^{1^{*}}$ \\ ${ }^{1}$ Department of Botany Prithvi Narayan Campus, Tribhuvan University, Pokhara, Nepal. \\ *For Correspondence: om.dwa@prnc.tu.edu.np
}

\begin{abstract}
The present paper is based on the work done about traditional uses of medicinal shrubs in Begnas-Rupa lake area from Oct 2018 to Apr 2019. This result was based on survey carried out consulting participatory techniques to collect information about collection and utilization of such plants on that area. Important information and other details about the respective plants were collected by discussion with native inhalers and traditional medicine practitioners. The result revealed that 20 Species of medicinal shrubs belonging to 17 families have been locally used Included families are Acanthaceae, Apocynaceae, Asclepidaceae, Asteraceae, Berberidaceae, Capparidaceae, Euphorbiaceae, Leguminosae, Loganiaceae, Lythraceae, Malvaceae, Melastomataceae, Oleaceae, Polygonaceae, Primulaceae, Rhamnaceae and Rutaceae.
\end{abstract}

Key words: Begnas-Rupa Lake area, ethnobotanically, medicinal plants, participatory techniques, traditional use.

\section{INTRODUCTION}

From the beginning of civilization, plants have served in many ways for the mankind and have been continuously used for various purposes. Plants have been the sources of medicine and food to mankind. The medicinal plants are the most important aspects of the creation that cures the various diseases. Plant materials were the basis of Ayurveda since time immemorial and now its contribution to human health care is deep rooted in rural villages of Nepal. Everyone uses medicinal plants in the treatment of diseases and normal illness.

Few attempts have been carried out previously from this area like Kayastha, (1982); Dwa (1994); Kayastha and Dwa (1997); Subedi and Dwa (1999); and Dwa et al. (2003). These papers dealt with herbs and trees with less shrubs and present attempt focused only on shrubs. So, the main objective of this study was to prepare a document of traditionally used shrubs from Begnas-Rupa Lake area.

\section{MATERIALS AND METHODS}

\section{Study area}

The study area for this paper lies in Begnas lake and Rupa lake and their surroundings. The site is located in the south-east of Pokhara valley. The elevation of studied area ranges from 490 to 1217 meters above sea level showing predominantly subtropical vegetation pattern.

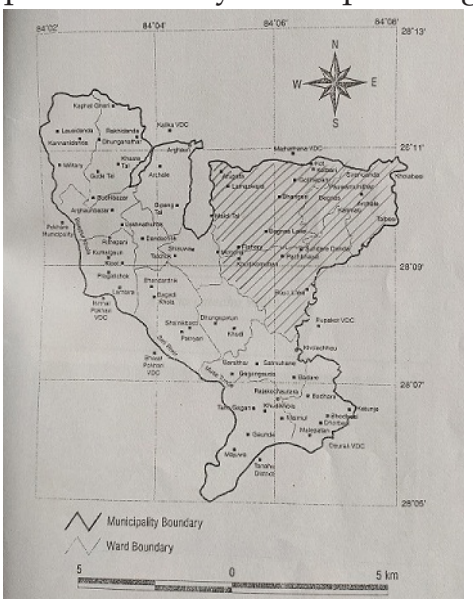

Figure 1: Study site 


\section{Method of data collection}

T. Data for this study were collected by twelve field trips. The study mainly focused on shrubs that have been used traditionally in the field of herbal therapy. During field trips, different information about such plants were collected interviewing with local people, traditional health workers and native inhalers particularly on methods of their uses. Collection of plant specimen, making field notes were done in the study area. The plant specimens were identified with the help of related documents, books and journals.

\section{Result and discussion.}

During this study, a total of 20 species of medicinally important shrubs were documented. They belong to 17 families. Taxonomy of the documented plant species is available elsewhere. The traditional uses of the documented plants are provided below.

\section{1) Adhtoda vasica. Nees.}

Vernacular name: Asuro, English common name: Malabar nut.

Family: Acanthaceae.

Partsused: Leaf and whole plant.

Uses: whole plant is useful but leaf is taken to cure respiratory problems like asthma, cough, bronchitis and whooping cough. The plant is also used to cure bleeding from nose and mouth and fever.

\section{2) Artemisia indica Willd.}

Vernacular name: Titepati

English common name: Mug-wort.

Family: Asteraceae.

Parts used: Leaf and whole plant.

Uses: The plant, mostly the leaf is useful in headache, asthma, bronchitis, gastritis and fever. The leaf is also used as antispasmodic, anthelmintic, insecticide, and stomachic. An infusion of leaves is treated to cure asthma, cut and wounds. Plant juice is also used to cure diarrhea and dysentery.

\section{3) Bauhinia variegata Linn.}

Vernacular name: Koiralo

English common name: Camel's foot tree.

Family: Leguminosae / sob-familyCaesalpinoidae.

Parts used: Root, Bark and Bud.

Uses: Root in combination with other drugs is used for treatment of snake bite. Bark is alterative, anthelmintic, cooling, laxative and appetizer. Bark is used in diarrhea, dyspepsia, asthma, cut, wound and ulcers. Juice of the bark is also useful in treatment of dysentery. Buds are used in piles, cough and eye-disease. Flower and floral bud are used to treat leucorrhoea. The flower is also taken to relief body pain and indigestion.

\section{4) Berberis aristata $\mathbf{D C}$.}

Vernacular name: Chutro.

English common name: Berberry.

Family: Barberidaceae.

Parts used: Root and root bark.

Uses: Root, particularly its decoction is useful to kill intestinal worms. Root bark is treated externally in eye-disease, skin problems and malarial fever. The plant shows alterative and astringent properties that mostly used to cure diarrhoea and jaundice.

\section{5) Buddleja asiatica Lour.}

Vernacular name: Bhimsenpati.

English common name: Butterfly bush.

Family: Loganiaceae.

Parts used: whole plant.

Uses: The plant is useful to cure skin problems and act as abortifacient.

\section{6) Calotropis gigantean(L.) Dryand.}

Vernacular name: Ank.

English common name: Sallow-wort.

Family: Asclepidaceae. 
Parts used: whole plant.

Uses: Root paste is applied to cure skin diseases like syphilis and leprosy and also useful in headache. The plant is useful in respiratory diseases like cough and asthma.

\section{7) Citrus medica Linn.}

Vernacular name: Bimiro. Finger citron / Citron. Family: Rutaceae.

Parts used: Root and fruit.

Uses: Root is anthelmintic and useful in vomiting and urinary calculus. Root juice is useful in constipation. Ripped fruits are stimulant, astringent, refrigerant and tonic.

\section{8) Crataeva religiosa Forst.}

Vernacular name: Sipligan.

English common name: Temple plant / Sacred garlic pear.

Family: Capparidaceae.

Parts used: Leaf and bark.

Uses: Its bark is stomachic, alterative, antipyretic, laxative and diuretic. The bark is also useful in disorders of urinary organs. Leaf is useful in urinary problems.

\section{9) Euphorbia royaleana Boiss.}

Vernacular name: Sihundi.

English common name: Cactus spurge.

Family: Euphorbiaceae.

Uses: The leaves are diuretic and purgative. The latex is also purgative, expectorant and deobstruent. The latex is also useful in burns and scalds to prevent formation of blisters.

\section{0) Hibiscus Rosa-sinensis Linn.}

Vernacular name: Baramase phool. English common name: Shoe-flower. Family: Malvaceae.

Parts used: Root, leaf, bud and flower.

Uses: Root juice is treated in cough and cold. Leaves are emollient and laxative. Buds used in burning of the body, seminal weakness, piles, uterine and urinary problems. Flowers used to check excessive menstruation and different kinds of inflammations.

11) Inula cappa DC.

Vernacular name: Laxhmi phool / Tihare phool. English common name: Sheep's Ear.

Family: Asteraceae.

Parts used: Leaves.

Uses: Leaf extract is used in pectoral complains. Leaf paste is useful to cure rheumatism pain.

12) Maesa chisia Buch.-Ham. ex D.Don.

Vernacular name: Bilouni.

English common name: NA

Family: Primulaceae.

Parts used: Root bark.

Uses: Root bark is used as insecticidal and to cure syphilis.

13) Mahonia napaulensis DC.

Vernacular name: Jamane mandro.

English common name: NA

Family: Berberidaceae.

Parts used: Bark and fruits.

Uses: Bark is of antidysenteric and antidiarrhoeic properties. Fruits or berries are of diuretic and demulcent properties.

14) Nerium odorum Sonald.

Vernacular name: Karbir / Kanar.

English common name: Indian oleander.

Family: Apocynaceae.

Uses: Root is powerful resolvent and paste is recommended for ulcer of the genitalia. Oil obtained from root bark is applied to cure leprosy and skin diseases. Flower is aphrodisiac and used in pain of muscles and joints.

15) Nyctanthus arbor-tristis Linn.

Vernacular name: Parijat.

English common name: Night jasmine.

Family: Oleaceae.

Parts used: Leaf. 
Uses: Leaves are used in fever, cough and rheumatism. Leaf juice is laxative, anthelmintic and diuretic. The leaf juice is used to cure asthma, sciatica and malaria fever.

16) Osbeckia nepalensis Hook.

Vernacular name: Setochulesi.

English common name: Nepal pink osbeckia.

Family: Melastomaceae.

Parts used: Flowers

Uses: Flower paste is useful to cure sores in oral part of children.

17) Polygonum molle D. Don.

Vernacular name: Thotne.

English common name: NA

Family: Polygonaceae.

Parts used: leaf.

Uses: leaves are used to cure diarrhoea.

18) Woodfordia fructicosa (L.) Kurz.

Vernacular name: Dhairo.

English common name: Fire-flame bush.

Family: Lythraceae.

Uses: Bark is taken raw to treat boils in tongue.

Dried flowers are astringent and tonic and useful to cure dysentery. Again, dried flowers with curdle is useful to cure internal haemorrhage. Flowers are used as safe stimulant in pregnancy and also useful to cure leucorrhoea, piles and liver complaints. Leaf paste is useful in skin problems and conjunctivitis. Flowers are useful to treat cough, cold and fever.

19) Zanthoxylem aramatum DC.

Vernacular name: Timmur.

English common name: Winged prickly ash.

Family: Rutaceae.

Parts used: Fruit.

Uses: Fruits are widely used to cure cold, gastriasis, abdominal pain and indigestion. Fruits are also taken for cough and toothache.

20) Ziziphus jujuba Lam.

Vernacular name: Bayar.

English common name: Indian plum.

Family: Rhamnaceae.
Parts used: Root, bark, leaves and fruits.

Uses: Root paste is used to cure dysentery and vomiting. Root juice is taken in case of fever, menstrual disorder, indigestion and peptic ulcer. Bark is useful to cure boils, dysentery and diarrhoea. Leaf is used to cure abdominal problems and obesity. Fruit is useful as aphrodisiac, laxative and cooling.

\section{ACKNOWLEDGEMENTS}

The Author expresses sincere thanks to $\mathrm{Mr}$. Navin Kumar Dewan, Faculty member of New Moonlight Secondary school for his help and participation during this work and to inhabitants of Begnas- Rupa lake area for necessary participation and discussion about plants and finally to Mr. Ambar Bahadur Baidhya, a traditional medicinal practitioner for his valuable information about Ayurveda medicine.

\section{REFERENCES}

Burlakoti, C. and R.M. Kunwar (2008). Folk Herbal Medicines of Mahakali Watershed Area. Medicinal Plants in Nepal, ECOS, Kathmandu. 188-194.

Dhami, N. (2008). Ethnomedicinal Uses of Plants in Western Terai of Nepal: A case study of Dekhatbhuli V.D.C., Kanchanpur. Medicinal Plants in Nepal, ECOS, Kathmandu, 165-177

Dutta. I.C. (2007). Non timber Forest Products of Nepal.

Dwa, O.P. (1994). The descriptive study on ethnobotanical plants of Shishuwa V.D.C.

Dwa, O.P.; N.D. Bastakoti; and H. Upadhyaya (2003). A case study on multiple uses of some wild plants of Begnas- Rupa Lake Area.

Gurung, L.J.; S. Rajdhandari, and S. Ranjitkar (2008). Indigenous Knowledge on Medicinal plants in Mid hills of Nepal: A case study 
of Sikles, Kaski. Medicinal Plants In Nepal, ECOS, Kathmandu, pp153-164.

Joshi, K.K. and S.D. Joshi (2001). Genetic Heritage of Medicinal and Aromatic plants of Nepal Himalayas.

Joshi, K.R. (2008). Ethnomedicinal Uses of Plants: A case study of Sharmoli V.D.C., Darchula. Medicinal Plannts In Nepal,ECOS, Kathmandu, pp178-187.1

Kayastha, R.S. (1982). Medicinal Plants of Pokhara Valley.

Kayastha, R.S. and O.P. Dwa (1998). Additional Works on Medicinal plants of Pokhara Valley.

Subedi, A. and O.P. Dwa (1999). Biodiversity of Begnas Lake Area of Kaski District, West Nepal. 